\title{
THE EFFECTIVENESS OF INQUIRY BASED LEARNING FOR NATURAL SCIENCE LEARNING IN ELEMENTARY SCHOOL
}

\author{
Dek Ngurah Laba Laksana \\ STKIP Citra Bakti, Nusa Tenggara Timur, Indonesia \\ Email: laba.laksana@gmail.com
}

\begin{abstract}
This paper primarily emphasized on describing the use of inquiry in natural science learning at primary school. This study also exposed the validity of inquiry strategy in natural science learning to improve primary schools students' comprehension. Further, this present study employed a library research sourced from reputable journal articles in relation to the issue. Assisted inquiry strategy with 5E model became the one investigated. The model covered five phases namely, engaging, exploring, explaining, elaborating, and evaluating. Empirically, the inquiry strategy in natural science learning had proven improving the quality of learning and the learning achievement, particularly in conceptual learning.
\end{abstract}

Keywords: inquiry, natural science learning

\section{Introduction}

Meaningful learning is a consequence of paradigm shifting from behaviourism to constructivism. Meaningful learning is also a reflection in context of $21^{\text {st }}$ learning that require a learning process which creates high quality of human resources. What it means to be high quality human resources is that having the ability to think critically, a problem-solver, and bringing beneficial effects for future (Jansen \& Merwe, 2015).

Emphasising on meaningful learning aims at improving life skills as the essence of constructivist paradigm (Anderson \& Krathwool, 2011). In the context of meaningful learning, learning should emphasize on inserting concepts, changing the background concept into critical scientific concept (Johnson, 2000). Thus, understanding a concept becomes fundamental to step on higher level of thinking (Minner, Levy, \& Century, 2009).

The previous empirical studies in natural science have proven the importance of understanding a concept (Niaz, 2005; Turkmen, 2006). One of the important objectives of research in natural science is constructing a method that can help students to understand a scientific concept from alternative concepts. Alternative concept is often called as misconception because conceptual development needs a different method to deliver natural science subject. Misconception is often experienced by teachers (Laksana, 2014; Jonhston, 2000) or prospective teachers (Laksana, 2012; Buaraphan, 2011) in most concepts of natural science in elementary schools. This misconception needs special treatments in a form of specific strategy. Direct instruction is hard to be implemented in this case (Calik dkk. 2007; Ates, 2005).

Essentially, science has two dimensions. The first is science as a product and as a process. Natural science is a collection of knowledge covering facts, concepts, principles, and theories which then be called as science as a product. Meanwhile, science as a process covers skills and attitude that is needed to gain and develop new knowledge (Sadia, 1998). Science is not merely about memorizing information. Today's learning perspective relies much on the product but less on the process. In fact, understanding the body of knowledge, particularly science, cannot be reached without understanding its process.

The essence of science as a product as well as a process encourages the use of inquiry strategy in science learning (NRC, 2002; Choi et al., 2008). Inquiry strategy can be seen as the umbrella of inductive approach (Prince $\&$ Felder, 2007) and quite suitable to be implemented for deep understanding.

The paradigm of learning is oriented to project, problems, and inquiry, invention and creation (Ardhana, 2000). In line with that, Arends (2011) states some suitable strategy for teaching nowadays such as project-based learning, case-based learning, research-based learning, situation-based learning, inquiry-based learning, and Problem-Based Learning (PBL). This empirical findings indicates that in every learning strategy needs an investigation.

Therefore, inquiry strategy is appropriate to be implemented for learning a concept as seen through constructivism theory. Inquiry strategy has been implemented several times in learning because of its beneficial effect on conceptual understanding development and cognitive strategy used in solving problems (NRC, 2002)

Inquiry based learning is claimed as the umbrella of inductive approach (Prince \& Felder, 2007) and it is applicable to build a deep understanding. In the process of learning, the essence of inquiry based learning are 
questioning and investigating students' prior knowledge. Therefore, inquiry based learning can be applied to understand a concept as seen from constructivism theory. Inquiry based learning has been applied several times in learning because of its beneficial effects in understanding a concept deeper as well as requiring critical thinking to solve a certain problem (NRC, 2002)

From the aforementioned explanation, this study aims at investigating the following matters, (1) how to design natural science learning in elementary schools by using inquiry based learning? (2) How is the effectiveness of inquiry-based learning in science subject in improving the quality of learning?

\section{Method}

This study is a library research that examines conceptual theories on how to design a teaching-learning process through inquiry based learning. Empirical study from any related literature and reputable journal articles are used as the source to solve the problems in this paper.

\section{Findings and Discussion}

\section{Designing Natural Science Learning with Inquiry Based Learning in Elementary Level}

Not all of science teachers apply this inquiry strategy. In fact, empirical findings prove that science learning should be based on inquiry based learning (Capps, \& Crawford, 2013). Inquiry learning is a strategy where teachers and students learn scientific phenomena with scientific approach. All of them consists of several aspects such as thinking process where students observe, predict, suggest, plan a research, formulate a hypothesis, interpret data, control variable, testing, communicate, and conclude it (Nuangchalerm, 2014).

Bruner states four reasons to use inquiry based learning, namely potential intelligence, intrinsic motive, heuristic of inquiry learning, and memory conservation. With the potential intelligence, Bruner conveys that an individual learns and develop their thoughts by using their potential. Bruner emphasizes that only people who learn through inquiry based learning has chance to do this.

Inquiry based learning is divided into three types, those are guided inquiry, free inquiry, and modified inquiry (Spencer \& Tracy, 2012). In its relation to learning in elementary school, guided inquiry is quite suitable to design an instruction. Guided inquiry utilises the 5E stages from Magee and Ryan (2012). The stages are engage, explore, explain, elaborate, and evaluate. It is a clear and attributive concept for teaching. This strategy uses this process to enable students to make their own definition from their understanding of a concept as follows.

1. Engagement. Teacher delivers one or more simple questions, but slowly drives them to more complex one. For instance, teacher begins with. "do you know that oil and gas come from fossil?"

2. Exploration. In this phase, students are divided intro groups to have scientific experiment. This structure and design help students to observe how is the layer of earth and fossil fuels

3. Explanation. Teacher explains how fossil fuels are formed by referring to ttext, journal articles, or internet source.

4. Elaboration. This phase includes making a trace of fossil, comparing fossil, and creating a model that simulate the process of how fossil fuels are created.

5. Evaluation. This phase focuses on accessing students understanding through any means possible such as questionnaire, journals, or field notes.

From those phases, the design of inquiry based learning in class is provided on the table 1 .

Table 1. Teaching and Learning Process in Inquiry based Learning

\begin{tabular}{|c|c|c|}
\hline \multirow{2}{*}{ Phase } & \multicolumn{2}{|c|}{ Learning Activities } \\
\hline & Teacher & Students \\
\hline \multirow[t]{4}{*}{ Engage } & 1) Building up students curiosity and interest & 1) Being curious about a topic \\
\hline & $\begin{array}{l}\text { 2) Confirming students' prior knowledge } \\
\text { about a concept or idea }\end{array}$ & $\begin{array}{l}\text { 2) Expressing their prior knowledge about the } \\
\text { topic }\end{array}$ \\
\hline & 3) Inviting students to express their ideas & 3) Asking their teacher particular question such \\
\hline & 4) Allowing students to ask questions & $\begin{array}{l}\text { as "Do I know about this? What do I feel about } \\
\text { this? How do I find this out?" }\end{array}$ \\
\hline \multirow[t]{3}{*}{ Explore } & $\begin{array}{l}\text { 5) Encouraging the interaction to happen } \\
\text { among students by grouping them }\end{array}$ & $\begin{array}{l}\text { 4) Investigating and observing, and then } \\
\text { describing as well as taking notes for their }\end{array}$ \\
\hline & $\begin{array}{l}\text { 6) Delivering a question to the group so that } \\
\text { each member can argue and express their } \\
\text { ideas }\end{array}$ & $\begin{array}{l}\text { data from the teacher's illustration } \\
\text { 5) Trying another strategy to solve their } \\
\text { problems }\end{array}$ \\
\hline & $\begin{array}{l}\text { 7) Giving enough time allotment for students } \\
\text { who are still confuse with the topic } \\
\text { (conflict cognitive) }\end{array}$ & $\begin{array}{l}\text { 6) Using their daily experience to help them } \\
\text { compare their ideas to their previous one } \\
\text { 7) Comparing ideas among students }\end{array}$ \\
\hline Explain & $\begin{array}{l}\text { 8) Encouraging students to utilise their } \\
\text { experience and the knowledge they get from }\end{array}$ & $\begin{array}{l}\text { 8) Explaining their concept by their own } \\
\text { language }\end{array}$ \\
\hline
\end{tabular}




\begin{tabular}{|c|c|c|}
\hline \multirow{2}{*}{ Phase } & \multicolumn{2}{|c|}{ Learning Activities } \\
\hline & Teacher & Students \\
\hline & $\begin{array}{l}\text { the engagement and exploration phase to } \\
\text { construct an explanation }\end{array}$ & $\begin{array}{l}\text { 9) Proving their explanation with evidences } \\
\text { from their result of investigation }\end{array}$ \\
\hline & $\begin{array}{l}\text { 9) Giving a guided questions to help them } \\
\text { construct an explanation }\end{array}$ & $\begin{array}{l}\text { 10) Noting the ideas and knowledge that they } \\
\text { get }\end{array}$ \\
\hline & 10) Asking for proofs and justification about & 11) Stating their ideas using scientific term \\
\hline & the students' explanation & 12) Comparing their ideas to other groups \\
\hline & $\begin{array}{l}\text { 11) Giving enough time for students to } \\
\text { compare their work with others as input for } \\
\text { revision }\end{array}$ & \\
\hline & $\begin{array}{l}\text { 12) Introducing particular terms and } \\
\text { alternative explanation after students } \\
\text { express their ideas }\end{array}$ & \\
\hline \multirow[t]{7}{*}{ Elaborate } & $\begin{array}{l}\text { 13) Focusing students' attention on the relation } \\
\text { between the new concepts and the concept }\end{array}$ & $\begin{array}{l}\text { 13) Linking the conceptual definition and their } \\
\text { experience }\end{array}$ \\
\hline & they create from experience & 14) Maximizing what they learned to explain a \\
\hline & 14) Encouraging students to use whatever they & new concept \\
\hline & learn to explain their ideas or new & 15) Explaining with scientific terms \\
\hline & phenomenon & 16) Describing their answers and concluding \\
\hline & $\begin{array}{l}\text { 15) Giving reinforcement to student with } \\
\text { scientific terms that has been introduced } \\
\text { previously }\end{array}$ & $\begin{array}{l}\text { from the data and evidences } \\
\text { 17) Sharing their understanding to other students }\end{array}$ \\
\hline & $\begin{array}{l}\text { 16) Delivering questions to help students in } \\
\text { reasoning }\end{array}$ & \\
\hline \multirow[t]{5}{*}{ Evaluate } & $\begin{array}{l}\text { 17) Observing and taking notes from students' } \\
\text { demonstration on explaining materials and } \\
\text { material delivery }\end{array}$ & $\begin{array}{l}\text { 18) Demonstrating what they understand about } \\
\text { certain concepts and hoow they apply their } \\
\text { skills }\end{array}$ \\
\hline & $\begin{array}{l}\text { 18) Interviewing students about meaning and } \\
\text { the improvement of their concepts }\end{array}$ & $\begin{array}{l}\text { 19) Comparing their thoughts to other students } \\
\text { and finding solution on how to revise their }\end{array}$ \\
\hline & 19) Encouraging students to di self-assessment & ideas \\
\hline & & 20) Conducting a self-assessment \\
\hline & & $\begin{array}{l}\text { 21) Delivering a deeper question about a certain } \\
\text { topic or concepts }\end{array}$ \\
\hline
\end{tabular}

In inquiry based learning, teacher comes up with a problem and asks students to decide the process to find the solution. A guided inquiry is very important to be implemented for some reasons, (1) students are expected to have good science literacy in solving their problems, and for that reason students need to actively participate in their level that is suitable to their science activity with teacher guidance, (2) this learning strategy is very important for young learners because they need a concrete experience of learning (Redhana, 2009)

From inquiry based learning, students will slow down their previous learning strategy to be able to organise and doing good observation. The biggest result in inquiry based learning is that students will have longer memory retention, thus they can apply it in a new situation. If students try to discover and build their knowledge independently, they will recall it and store it longer. Glazer's study shows that guided inquiry really helps students' development in solving problems, being creative, and doing an independent study.

Furthermore, inquiry based learning also helps students to be more responsible of their work. They also feel motivated when they learn to find new knowledge and process it within themselves. They are driven to be an autonomous learner who is inner-directed. For them, recognition of their work is the effort itself. They learn to actively manipulate their surroundings. They will reach satisfaction from being able to solve a problem. Bruner believes that students receive a satisfying intellectual sensation as an intrinsic appreciation. On the other side, teachers can give extrinsic reward. If teachers want their students to learn comfortably, they need to plan a learning situation that triggers students' intrinsic recognition (Redhana, 2009).

Inquiry based learning enables teachers to provide a proper situation to stimulate students to learn. Teacher's role is to be a facilitator who is responsive to student's needs. Teacher's position as the source of information and reward provider needs to be put aside and let students to try without any hesitation.

The essence of guided inquiry based learning is questioning (Cook \& Gayle, 2014). Questioning does not only help teachers to decide what is already known by students, but also push them to learn more diligently. Questioning is a basic to inquiry based learning or constructivist learning (Carin, 1997). In relation to questioning, Lawson states that in order teacher to succeed in teaching, they need to use this strategy to guide and direct students to have their own investigation. In guiding the students, teacher can deliver two types of questions such as divergent or evaluative questions. Divergent and evaluative questions will attract some response from students and trigger their creativity to think critically. Divergent questions do not expect a single absolute answer but plural. On the other hand, convergent question is the one which needs single absolute answer (Redhana, 2009). 
To sum up, this study proves that students tend to choose inquiry based learning compared to books oriented science learning. Inquiry based learning will cause students to: 1) love science more because it is fun and interesting; 2) try to obtain more knowledge on natural science; 3) feel that science is very applicable for their daily life; and 4) having positive perspective on science (Llewellyn, 2013).

\section{The Effectiveness of Inquiry Based Learning in Natural Science Learning as an Effort to Fix the Quality of Learning}

According to the theory of instructional design, the learning outcome is the overall effect which can be used as indicators about score and learning method in a certain situation. The learning outcome cover a broad sense of aspects starting from effectiveness, efficiency, and appeal (Reigeluth, 1999). From the effectiveness aspect (the achievement of instructional goals), it covers cognitive areas, affective and psychomotor. The cognitive areas also has a large cover and therefore a new specific taxonomy is needed for this area to specify and clearing the instructional goals to study the effectiveness of a learning method.

Some taxonomy are stated to understand how deep cognitive areas influences the learning outcome. The taxonomy stated actually has some similar characteristics each other, yet they have other term to express it.

The goals of education does not only emphasize on the amount of knowledge and materials, especially only recalling some facts. In line with that statement, Gagne (1985) argues that students' learning condition is directed to let them practice to solve problems. It is high capability in thinking skills and conceptual understanding. Its relation to the goals of education is to develop the ability to understand a concept, and it has been proven by a number of experts (Young et al., 1996; Warpala, 2008).

The undergoing process to gain a new knowledge need to consider students' prior knowledge (Dochy, 1996) and the utilisation of surroundings as the learning source (Capps \& Crawford, 2013). It implies that teacher should optimize the quality of learning through careful selection of teaching method or strategy and referring to the variation of message delivery, curriculum substance, and direct them toward deep understanding. Based on this explanation, reaching the learning goals should cover four major aspects, 1) choosing appropriate method or strategy, 2) accommodating students prior knowledge in learning, 3) utilising the surrounding condition which the students can get in touch with, 4) changing in assessment procedure so that it corresponds to the essential goal of science learning.

This study also focuses on cognitive learning outcome, particularly on the understanding aspect. Accordingly, Wiske \& Beatty (2009:232)states that The teaching for understanding framework emphasizes goals that require students to go beyond "the information given", to construct their own understanding, and to apply their knowledge flexibly and creatively.

Kima (2012) finds out that a good and well-structured inquiry based learning can improve beginners in natural science learning. This is supported by Kim et al. (2014) who reveal that there is a significant difference in students' natural science learning achievement and their attitude to science.

\section{Conclusion}

From the aforementioned explanation, the researcher comes to two conclusions, 1) there are several steps to design learning with inquiry based learning, those are engagement (delivering one or more simple questions and slowly moves to the complex one), exploration (grouping students to have an experiment), explanation (teacher explains the material by referring to various sources such as books, journal articles, internet), elaboration (finding solution, comparing to other studies, creating a model to proof a theory), evaluation (teacher tries to get access to students knowledge through tests, questionnaire, journal, or field notes). (2) Inquiry strategy has proven empirically being able to improve the quality of learning particularly on learning a concept.

\section{References}

Anderson, L.W. \& Krathwohl, D.R. (2001). A Taxonomy for Learning, Teaching, and Assessing. Abridged Edition. New York: Addison Wesley Longman, Inc.

Ardhana, W. (2000). Reformasi Pembelajaran Menghadapi Abad Pengetahuan. Makalah. Disajikan dalam Seminar dan Diskusi Panel Nasional Teknologi Pembelajaran V. Prodi TEP Pascasarjana Universitas Negeri Malang dan IPTPI Cabang Malang, tanggal 7 Oktober 2000.

Arends, R.I. (2011). Learning to Teach 9th. New York: McGraw Hill Companies

Ates, S. (2005). The effects of Learning Cycle on College Student' Understandings of Different Aspect in Resistive DC Circuit. Elektronic Journal of Science Education, [online], 9(4) (http://wolfweb.unr.edu/homepage/crowther/ ejse/ates.pdf, diakses 21 Desember 2014

Buaraphan, K. (2011). Pre-service Physics Teachers' Conceptions of Nature of Science. China Education Review, $8(2), 137-148$ 
Calik, M., Ayas, A. \& Coll, R.K. (2007). Enhancing Pre-Service Elementary Teachers' Conceptual Understanding of Solution Chemistry With Conceptual Change Text. International Journal of Science and Mathematics Education, 5(2007), 1-28

Capps, D.K. \& Crawford, B.A. (2013). Inquiry-based instruction and teaching about nature of science: are they happening? Journal of Science Teacher Education, 24(3), 497-526

Choi I., Lee, S.J., \& Jung, J.W. (2008) Designing Multimedia Case-Based Instruction Accomodating student's Diverse Learning Style. Journal of Educational Multimedia and Hypermedia, 17 (1), 5-25

Cook, K. \& Gayle B. (2014). Pre-service elementary teachers' experience in a community of practice through a place-based inquiry. International Journal of Environmental \& Science, 9 (1), 111-132

Dochy, F.J.R.C. (1996). Prior Knoledge and Learning. Dalam E.D. Corte \& F. Weinert (Eds): International Encyclopedia of Development and Instructional Psycology. New York: Pergamon.

Jansen, C. \& Merwe, P. (2015). Teaching Practice in the 21st Century: Emerging Trends, Challenges and Opportunities. Horizon Research Publishing. [online] melalui Error! Hyperlink reference not valid. $=\mathrm{EJ} 1056080$

Johnstone, A. H. (2000). Chemical education research: Where from here? University Chemistry Education, 4, 3438

Joyce, B. \& Weil, M. (2003). Models of Teaching $5^{\text {th }}$. New Delhi: Prentice HaII of India

Kim, H.R, Choi, S.Y., Lee, K.J. (2014). The effect of question-generating strategy for science inquiry instruction in elementary science class. Journal of Korean Elementary Science Education, 33(4), 700-709

Kirna, I M. (2012). Conceptual chemistry understandings of beginning learners in interactive multimedia-based instruction. Jurnal Ilmu Pendidikan, 18(1), 88-97

Laksana, D.N L. (2012). The profile of misconception in science subject at elementary school by students of elementary school teacher education department Ganesha Education University UPP II Denpasar in academic year 2011/2012 (Unpublished thesis), Basic Education Graduate Program, University of Ganesha Education, Indonesia.

Laksana, D.N L. (2014). The profile of conception in science subject at elementary school by teacher of elementary school in Ngada Regency. Journal of Pendidikan Citra Bakti, 1 (1), 15-26.

Llewellyn, D. 2013. Teaching high school science through inquiry and argumentation, 2nd Edition. California: Corwin a SAGE Company.

Magee, P.A. \& Ryan F. (2012). Collaborating to improve inquiry-based teaching in elementary science and mathematics method courses. Science Educational International, 23 (4), 353-365.

Minner, D.D., Levy, A.J., \& Century, J. (2009). Inquiry-based science instruction-what is it and does it matter? Journal of Research in Science Teaching, 1-24

Niaz, M. (2005). How to facilitate students' conceptual understanding of chemistry?: A history and philosophy of science perspective. Retrieved from http://old.iupac.org/publications/ cei/vol6/05Niaz.pdf

NRC - National Research Council. (2000). Inquiry and the national science education standards: A guide for teaching and learning, DC: National Academies Press.

Nuangchalerm, P. (2014). Inquiry-based learning in China: lesson learned for school science practices. Asian Sosial Science, 10 (13), 64-71

Prince, M. \& Felder, R. (2007). The many faces of inductive teaching and learning. Journal of College Science Teaching, 36(5), 14-20.

Redhana, I W. (2009). Pengembangan Program Pembelajaran Berbasis Masalah Terbimbing Untuk meningkatkan Keterampilan Berpikir Kritis Siswa pada Mata Pelajaran Kimia SMA. Disertasi. Bandung: UPI.

Reigeluth, C.M. (1999). What is Instructional Design Theory and How is it Changing? Dalam C.M. Reigeluth (Ed.). Instructional Design Theory and Model, Vol. 2 (pp. 5-29). London: Lawrence Erlbaum Associates.

Sadia, I Wayan. 1998. Reformasi Pendidikan Sains (sains) Menuju Masyarakat yang Literasi Sains dan Teknologi. Orasi Pengukuhan Guru Besar Tetap. Singaraja: STKIP Singaraja.

Spencer, T.L. \& Tracy M.W. (2012). Creating a love for science for elementary students through inquiry-based learning. Journal of Virginia Science Education, 4 (2), 18-25

Turkmen, H. (2006). What Technology Plays Supporting Role in Learning Cycle Approach for Science Educational. TOJET, 5 (2), 1303-1321

Warpala, I.W.S. (2008). Pengaruh Pendekatan Pembelajaran dan Strategi Belajar Kooperatif yang Berbeda terhadap Pemahaman dan Keterampilan Berpikir Kritis dalam Pembelajaran sains di SD. Desertasi. Malang: Universitas Negeri Malang.

Wiske, M.S. \& Beatty, B.J. (2009). Fostering Understanding Outcome. Dalam C.M. Reigeluth, \& A.A. CarrCheliman (Eds.), Instructional-Design Theories and Models: Building a Common Knowledge Base, Vol. 3 (pp. 195-197), New York: Routledge

Young, M.F., Nastasi, B.K., \& Braunhardt, L. (1996). Implementating Jasper Immersion: A Case of conceptual change. Dalam B.G. Witson (Ed): Constructivist Learning Environment: Case Studies Instructional Design, (pp 121-133). Englewood Cliff, New Jersey: Educational Technology Publication, Inc. 